\title{
Genomic Library
}

National Cancer Institute

\section{Source}

National Cancer Institute. Genomic Library. NCI Thesaurus. Code C15241.

A collection of DNA molecules, derived from restriction fragments that have been cloned in vectors, that includes all or part of the genetic material of an org anism. 